\title{
Hannah Arendt and the quarrel of ancient and modern: 'On humanity in dark times: thoughts on Lessing' and the politics of historiography
}

Article

Accepted Version

Harloe, K. (2018) Hannah Arendt and the quarrel of ancient and modern: 'On humanity in dark times: thoughts on Lessing' and the politics of historiography. Classical Philology, 113 (1). pp. 20-38. ISSN 0009-837X doi:

https://doi.org/10.1086/695441 Available at https://centaur.reading.ac.uk/72116/

It is advisable to refer to the publisher's version if you intend to cite from the work. See Guidance on citing.

Published version at: http://www.journals.uchicago.edu/doi/abs/10.1086/695441

To link to this article DOI: http://dx.doi.org/10.1086/695441

Publisher: University of Chicago Press

All outputs in CentAUR are protected by Intellectual Property Rights law, including copyright law. Copyright and IPR is retained by the creators or other copyright holders. Terms and conditions for use of this material are defined in the End User Agreement. 


\section{CentAUR}

Central Archive at the University of Reading

Reading's research outputs online 


\section{Hannah Arendt and the Quarrel of Ancient and Modern}

\section{'On Humanity in Dark Times: Thoughts on Lessing' and the politics of historiography}

We can no longer afford to take that which was good in the past and simply call it our heritage, to discard the bad and simply think of it as a dead load which by itself time will bury in oblivion. The subterranean stream of Western history has finally come to the surface and usurped the dignity of our tradition. This is the reality in which we live. And this is why all efforts to escape from the grimness of the present into nostalgia for a still intact past, or into the anticipated oblivion of a better future, are vain.

Arendt, The Origins of Totalitarianism $(1950)^{1}$

A century after her birth and four decades since her death, Hannah Arendt has in many ways never seemed more modern. The concerns that occupied her in the mid-twentieth century the fragility of toleration and the precarity of refugees; the human requirement for a homeland as a place of physical safety and political freedom; the pitfalls of nationalism and the fragility of cosmopolitanism; the nature of genocide and the unique form of justice it demands - also govern our post-1989, post-9/11 era. Arendt's writings are a source of critical inspiration to political theorists as diverse as Gorgio Agamben, Bonnie Honig, Seyla

\footnotetext{
${ }^{1}$ Arendt 1976, ix.
} 
Benhabib and Judith Butler. ${ }^{2}$ Understanding of her thought has been enriched by the posthumous publication of new material: the important and fascinating correspondence with Karl Jaspers and Kurt Blumenfeld, her working diary for the years 1950 to 1973, and the numerous early essays which - without settling the debates that continue to rage around her most controversial book, Eichmann in Jerusalem - are facilitating a more nuanced understanding of her relationship to both her Jewish heritage and the twentieth-century project of the state of Israel. ${ }^{3}$ Since the 1990s feminists have turned afresh to Arendt's writings, moving beyond condemnation of her apparent indifference to 'The Woman Question' to interrogate her thought's potential to contest and destabilise sedimented social and political hierarchies that entrench gender-based oppression. ${ }^{4}$ Her work is increasingly debated in ecopolitics and environmental philosophy as a source of insights into the relation between humanity and the world (both natural and manmade) and the dependence of the fate of each upon that of the other. ${ }^{5}$

What has this new generation of interlocutors made of the manifold turns of antiquity in Arendt's writings? From her 1920s doctoral dissertation on 'The Concept of Love in St Augustine', to the reflections on ancient republics contained in On Violence (1970), there can be no doubt of the importance to Arendt of what she explicitly theorised as a tradition of political thought that derives from Greece and Rome. Above all the classical Greek polis forms a central, positive example within The Human Condition (1958), the book generally

\footnotetext{
${ }^{2}$ Honig 1993, 2015, and in this volume; Benhabib 1996, 2002, 2006; Agamben 2005; Butler 2011, 2015.

${ }^{3}$ Arendt 1978, 1985, 1995, 2002, 2007a. On the 'Arendt Wars', see recently Robin 2015.

${ }^{4}$ See in particular the contributions to Honig 1995a.

${ }^{5}$ De Geus 2007, Voice 2013.
} 
considered her philosophical magnum opus, where it furnishes a shining example of her central category of politics-as-freedom or 'action'. Arendt's turn to the Greeks has nevertheless confronted many commentators as something of an embarrassment: her admiration of the polis, with its constitutive exclusions of women, foreigners and slaves, an obstacle in the way of uncovering whatever potential her thought may hold for the present.

Here, for example, is Hanna Fenichel Pitkin commenting on Arendt's turn to the Greeks in The Human Condition's second chapter on 'The Public and the Private Realm'. For Pitkin, this move is fundamental to Arendt's argument:

Although politics has already been linked to action in the opening chapter, chapter 2 elaborates that link and lends it authority by way of the ancient Greeks, in effect transferring to politics and free citizenship some of the liberating, generative conceptual role played by the idea of action...

At the same time, however, the ancient Greeks also import into Arendt's argument some problematic features she surely did not (consciously) intend to adopt: an agonistic, narcissistic, and misogynistic striving for heroic glory... and a corresponding set of rigid, pejorative contrasts ranking Greek above barbarian, freeman above slave, public above private, and male above female.

Pitkin continues, 'Arendt herself, of course, would not knowingly have endorsed any of these ranking. ${ }^{6}$ Her sense of the problem posed by Arendt's Greeks prompts her own turn to psychobiography, explaining Arendt's philhellenism as the product of her hostility to her mother and her ambivalent cleaving to the absent, quasi-paternal authority of Martin Heidegger. ${ }^{7}$ Her interpretation builds, with abundant acknowledgement, upon Benhabib's

\footnotetext{
${ }^{6}$ Pitkin 1998, 148.

${ }^{7}$ Pitkin 1998, see too Pitkin 1981.
} 
influential reading of Arendt as a 'Reluctant Modernist', which set out to distinguish Arendt, 'the stateless and persecuted Jew... the philosophical and political modernist' from Arendt 'the student of Martin Heidegger... the antimodernist Grecophile theorist of the polis and of its lost glory', and to recuperate the former but not the latter. ${ }^{8}$ For these commentators, Arendt's invocations of the ancients amount to an awkward intellectual legacy, a late example of the famous and fateful 'tyranny of Greece over Germany' she would have done better to repudiate. ${ }^{9}$

Arendt's turn to antiquity also generates a second, more specific paradox, which arises because of her particular theorisation of modernity. From The Origins of Totalitarianism onwards Arendt insists that a fundamental fact of contemporary life is the breaking, to use one of her own favourite metaphors, of 'the thread of tradition'. ${ }^{10}$ The rupture in thought and experience made evident in her own time by the phenomena of totalitarian domination on the one hand, and the threat of total nuclear destruction on the other, is absolute, and the inadequacy of traditional categories of Western political, moral and legal thought to grasp these unprecedented and horrific possibilities marks the end of that tradition. What point can there be in invoking the ancient past under such circumstances? Why dwell upon the Greek, Roman and Christian origins of a tradition all but annihilated in the horrors of the present?

It so happens that the second problem points the way towards solution of the first, because it hints at an issue with how the first has been framed. The difficulty with Benhabib's and Pitkin's readings is not just that they necessitate jettisoning some central Arendtian themes and indeed texts (Benhabib talks explicitly about aiming to 'decenter' The Human Condition

\footnotetext{
${ }^{8}$ Benhabib 1996, xxxviii-xxix.

${ }^{9}$ Butler 1935.

${ }^{10}$ Arendt 2006a: 13; see too Arendt 1973, vii, ix.
} 
from Arendt's oeuvre), but also that they cast Arendt's relation to antiquity as a matter of 'legacy' or 'inheritance', when much of her thought aims precisely at criticising, complicating and trying to think us away from such notions. ${ }^{11}$ There is something in this line of interpretation that is false to the texture, the weft and weave, of Arendt's writings, not merely because (as Pitkin acknowledges) she would herself have rejected such readings, but also because she devoted so much time and effort to theorising the break with past thought and practice forced upon herself and her contemporaries. It is therefore worth considering whether there is an alternative way of understanding Arendt's turns to antiquity, which does more justice to her consistent references to the ancients while also taking account of her insistence that there can be no nostos.

I argue below that such an interpretation can be found if we turn from Arendt's analysis of politics to her discussion and practice of historiography. Arendt's historiography exemplifies a turn to the Greeks at least as important as the analysis of polis life presented in The Human Condition. Its character is such as to complicate any understanding of her as split between ancient and modern. My argument will concentrate on the triad of essays on tradition, history and authority that begins the 1961 collection, Between Past and Future. First, though, I shall consider the essay 'On Humanity in Dark Times: Thoughts about Lessing', which opens her 1968 collection, Men in Dark Times.

Although originally an occasional piece (it was Arendt's acceptance speech upon award of the city of Hamburg's triennial Lessing Prize in 1959, and was originally published in German the following year) this essay displays several of the themes I wish to develop in relation to Arendt and historiography. It also Arendt's most extended treatment of a German classical figure who hovers in the background of many of her most immediately engaged

${ }^{11}$ Benhabib 1996, xxv. 
political writings, from 'The Enlightenment and the Jewish Question' (1932) to the controversies over Eichmann in the 1960s. ${ }^{12}$ As other commentators have noted, the figure of Lessing presented in 'On Humanity in Dark Times' is radically different from that of Arendt's earliest writings. ${ }^{13}$ In both 'The Enlightenment and the Jewish Question' and the chapter of The Origins of Totalitarianism devoted to 'The Jews and Society', Lessing serves as a figurehead for the failed approach to religious diversity developed in the Enlightenment, which allowed a limited number of 'exception' Jews access to society on condition they surrender their particular history and identity as Jews. ${ }^{14}$ By contrast, the Lessing of 'On Humanity in Dark Times' presents a paradigm - as unusual in the eighteenth century as in Arendt's own day - of that kind of cherishing of the public realm as one of plurality and distance that Arendt holds to be necessary to the creation and maintenance of the human freedom and that she associates above all with the ancients. It is this Lessing who is invoked at key moments of both Between Past and Future and The Human Condition, as providing an alternate, resistant perspective to the destructive intellectual and social tendencies of the

$\overline{12}$ Arendt 2007b, German publication Arendt 1960.

${ }^{13}$ See especially Arendt 2007b, 3-6, 16; 1997, 90; 1976, 56-68. The change in Arendt's view of Lessing is noted or discussed by Young-Bruehl 1982, 94-5, Petuchovski 1988, 33; Disch 1993, Weissberg 2007, Davies 2015.

${ }^{14}$ Arendt 2007, 3-18; Arendt 1976, 56-59; see too 'The Jew as Pariah: A Hidden Tradition', in Arendt 2007, 275-297. For a perceptive discussion of the issues to which Arendt is responding, with particular reference to Lessing's friend and intellectual collaborator, Moses Mendelssohn, see Leonard 2012, 17-64. Davies 2015, who sets Arendt's Lessing in the context of a chain of engagements with him stretching from his bicentenary in 1929 to the post-War era, shows that the terms of Arendt's early critique were standard in the Zionist circles in which she was working in the 1930s. 
nineteenth and twentieth centuries. This is a Lessing who stands out against the currents of the modern age, representing in some sense a bridge from antiquity to whatever possibilities Arendt sees for political action in the present.

\section{Lessing, classicality, and friendship}

Arendt's treatment of Lessing in the volume Men in Dark Times is paradoxical in ways that are paradigmatic of her historiographic approach. There is, first, a breath-taking anachronism in the way she incorporates Lessing into her collection:

The people assembled here could hardly be more unlike each other, and it is not difficult to imagine how they might have protested, had they been given a voice in the matter, against being gathered into a common room, as it were. For they have in common neither gifts nor convictions, neither profession nor milieu; with one exception, they hardly knew each other. But they were contemporaries, though belonging to different generations - except, of course, for Lessing, who, however, in the introductory essay is treated as though he were a contemporary. Thus they share with each other the age in which their life span fell, the world during the first half of the twentieth century with its political catastrophes, its moral disasters, and its astonishing development of the arts and sciences. And while this age killed some of them and determined the life and work of others, there are a few who were hardly affected and none who could be said to be conditioned by it. Those who are on the lookout for representatives of an era, for mouthpieces of the Zeitgeist, for exponents of History (spelled with a capital $\mathrm{H}$ ) will look here in vain. ${ }^{15}$

${ }^{15}$ Arendt 1968, vii-viii, emphases mine. 
The anachronism of Arendt's decision to treat Lessing 'as if he were a contemporary', is surely pointed, and this introductory passage raises questions about the collection as a whole. Why does Arendt emphasise that figures discussed her volume - public figures like Pope John and personal friends like Randall Jarrell, revolutionaries such as Rosa Luxemburg and philosophers such as Karl Jaspers, famous writers like Berthold Brecht and as-yet obscure ones like Walter Benjamin - were contemporaries? What is the meaning of her puzzling claim that although the age in which they lived 'determined the life and work' of some of them, 'none... could be said to be conditioned by it'?

The beginnings of an answer are provided by Arendt's observation that Lessing, like the twentieth-century figures she discusses, lived in 'dark times'. Part of what she appears to mean by this are the political conditions of unfreedom and censorship that characterised ancien régime Europe, which deprived Lessing of a stable public realm of speech and action in which to carry out his intellectual activities. Thus she comments that 'The German public was not prepared for him and as far as I know never honored him in his lifetime', a theme that returns in her shorter essay on Randall Jarrell. ${ }^{16}$ The claim that Lessing, of all people, was denied recognition within his own lifetime is perhaps surprising; yet it serves to underline Arendt's point that the public realm is a human creation, the product of free human speech and action, the generation and maintenance of which is also an ongoing and communal concern. As a truly politikon zōon, who was famously disputatious by nature and who hankered after a public realm of free discourse while living under the constraints of an absolute monarchy, Lessing could not but be untimely (unzeitgemäß) in Nietzsche's sense. Arendt consequently emphasises the loneliness of Lessing's final years: 'For a man of

${ }^{16}$ Arendt 1968, 5. 
Lessing's disposition there was little room in such an age and in such a confined world; where people moved together in order to warm one another, they moved away from him., ${ }^{17}$

But Arendt's introduction also makes it clear that her conception of 'dark times' involves a further, epistemic dimension. They are times rendered obscure by the insufficiency of thought to experience: humans' literal inability to describe and comprehend their social and political environment in the language and concepts bequeathed by tradition. ${ }^{18}$ In Arendt's own 'dark times' (which in this essay comprise principally Hitler's Germany, but also the will-to-forgetting or 'incapacity to face the reality of the past' Arendt diagnoses in her prior homeland after the $\operatorname{war}^{19}$ ), a major cause of obscurity was the deliberate distortions of language generated by totalitarianism, which allowed Nazi functionaries to shield themselves from the moral reality of their acts. Thus in her introduction Arendt takes time to indict a form of 'speech that does not disclose what is but sweeps it under the carpet, by exhortations, moral and otherwise, that, under the pretext of upholding old truths, degrade all truth to meaningless triviality': a formulation that, while reminiscent of Heidegger's characterisation of inauthenticity/das Man, also finds echoes in her analysis of Eichmann. ${ }^{20}$ A sense of the instability of thought and understanding in Lessing's era emerges at various points in the Lessing essay, in particular in Arendt's comment that 'Lessing's humanity... emerged in a

\footnotetext{
${ }^{17}$ Arendt 1968, 30-31.

${ }^{18}$ Luban 1983, 218; Disch 1993, 288; Weissberg 2007, 192-3.

${ }^{19}$ Arendt 1968, 19; this aspect of Arendt's essay, and it confirmation by the (lack of) reception of her original speech in the German press, is discussed by Eigen 2000 and Davies 2015.
}

${ }^{20}$ Arendt 1968, viii; see Arendt 2006b, 85-6, 150. 
politically enslaved world whose foundations, moreover, were already shaken. ${ }^{21}$ This metaphor, which she takes over from Lessing's characterisation of Diderot and applies first to Lessing's own critical activity, is most straightforwardly understood as a reference to the political ruin of the ancien régime in the French Revolution, which was to break out less than a decade after Lessing's death. ${ }^{22}$ As we shall see in more detail below, however, Arendt held that the political and social turmoil of the period after 1789 had its epistemic analogue and anticipation in the realm of thought.

Arendt asserts that Lessing felt his worldly privation keenly; she admires him nonetheless for acting at all times out of a commitment to the world:

His attitude toward the world was neither positive nor negative, but radically critical and, in respect to the public realm of his time, completely revolutionary. But it was also an attitude that remained indebted to the world, never left the solid ground of the world, and never went to the extreme of sentimental utopianism. ${ }^{23}$

This commitment was manifest throughout Lessing's cultural and intellectual efforts, from the editing of journals to the composition and criticism of dramas. It motivated his love of polemic and shaped his rhetorical style. ${ }^{24}$ Lessing's sensitivity to the worldly position of

${ }^{21}$ Arendt 1968, 30, emphasis mine.

22 'Diderot ist einer von den Weltweisen, welche sich mehr Mühe geben, Wolken zu machen, als zu zerstreuen. Ueberall wo sie ihre Augen hinfallen lassen, erzittern die Stützen der bekanntesten Wahrheiten, und was man ganz nahe vor sich zu sehen glaubte, verlieret sich in eine ungewisse Ferne.' Lessing 1890, 95; see Arendt 1968, 5; 26 (where she includes Lessing among those 'who take more trouble to make clouds than to scatter them').

\footnotetext{
${ }^{23}$ Arendt 1968, 5.

${ }^{24}$ Arendt 1968, 5.
} 
others was so great that it could lead him into contradiction, as when he attacked Christianity in one place and defended it from in another. Arendt interprets this inconsistency as a virtue: the result of his fundamental concern to preserve and foster the plurality of standpoints that make up the human world:

Criticism, in Lessing's sense, is always taking sides for the world's sake, understanding and judging everything in terms of its position in the world at any given time. Such a mentality can never give rise to a definite world view which, once adopted, is immune to further experiences in the world because it has hitched itself firmly to one possible perspective... To be sure, we are still aware that thinking calls not only for intelligence and profundity but above all for courage. But we are astonished that Lessing's partisanship for the world could go so far that he could even sacrifice to it the axiom of noncontradiction, the claim to self-consistency, which we assume is mandatory to all who write and speak.

Arendt comments, 'We very much need Lessing to teach us this state of mind'. ${ }^{25}$ She invokes him as a contemporary not just because his dark times share features in common with her own, but also because his practice as a thinker and writer was fundamentally concerned with the preservation of a humanly shared world of plural and diverging viewpoints. But, in addition to dubbing Lessing a contemporary, Arendt also and in equally pointed fashion terms his stance and practice 'classical'. This again smacks of paradox, for Arendt applies the term to Lessing's drama, Nathan der Weise, despite characterising the same play a page or two later as non-tragic. The paradox is resolved, however, when she explains what it is

${ }^{25}$ Arendt 1968, 8. 
she finds so classical in Nathan: the centrality to this play, with its emphasis on the bonds between Jew, Christian, and Muslim, of what she casts as a 'classical' notion of friendship. ${ }^{26}$

Arendt approaches the topic of friendship by way of its contrast to eighteenth-century notions of 'fraternity' (brotherhood in common suffering) and 'compassion' (pity for the suffering of others), both of which she associates with Rousseau. For Arendt, the difference between these understandable, even natural, sentiments, and friendship corresponds to the difference between worldlessness and commitment to the world. She argues that both fraternity and compassion involve a fusion of identities, a sense of intimacy and lack of distinction that tends to take hold particularly among pariah peoples in conditions of oppression and exclusion. By contrast, the classical conception of 'friendship' is 'public', in Arendt's sense, turning around discourse between distinct individuals who recognise both their plurality and their common concern:

$[F]$ or the Greeks the essence of friendship consisted in discourse. They held that only the constant interchange of talk united citizens in a polis. In discourse the political importance of friendship, and the humanness peculiar to it, were made manifest. This converse (in contrast to the intimate talk in which individuals speak about themselves), permeated though it may be by pleasure in the friend's presence, is concerned with the common world... The Greeks called this humanness which is achieved in the discourse of friendship philanthropia, "love of man," since it manifests itself in a readiness to share the world with other men. ${ }^{27}$

\footnotetext{
26 ' $[\mathrm{M}]$ odern as it is, [Nathan, the Wise $]$ might with some justice be called the classical drama of friendship'; 'the dramatic but untragic conflict of Nathan the Wise' (Arendt 1968, 25, 27). ${ }^{27}$ Arendt 1968, 24-5. Like so much of her understanding of Greek politics, Arendt's understanding of the classical conception of 'the political importance of friendship' in
} 
Just as the overall view of Lessing developed in this essay is considerably more positive than Arendt's earlier picture of him, so her reception of Nathan diverges greatly from her earlier interpretation. While Arendt's earlier readings of Lessing's drama of toleration focus upon the famous parable of the rings Nathan offers in the play's central act, criticising it for embodying an understanding of universal 'humanity' based on the erasure of particular characteristics, in the Lessing essay Arendt calls attention instead to the earlier scene in which Nathan exhorts the Templar with the words, 'Wir müssen, müssen Freunde sein!' ('We must, must be friends!'):

That humaneness should be sober and cool rather than sentimental; that humanity is exemplified not in fraternity but in friendship; that friendship is not intimately personal but makes political demands and preserves reference to the world - all this seems to us so exclusively characteristic of classical antiquity that it rather perplexes us when we find quite kindred features in Nathan the Wise - which, modern as it is, might with some justice be called the classical drama of friendship. What strikes us as so strange in the play is the "We must, must be friends," with which Nathan turns to the Templar, and in fact to everyone he meets; for this friendship is obviously so much more important to Lessing than the passion of love that he can brusquely cut the love story off short (the lovers, the Templar and Nathan's adopted daughter Recha, turn out to be brother and sister) and transform it into a relationship in which friendship is required and love ruled out. The dramatic tension of the play lies solely

antiquity' is grounded in Aristotle: in this case, the discussion of friendship/philia (including 'civic friendship' or politike philia) in Books 8-9 of the Nicomachean Ethics. For a broader discussion of the importance of Aristotle to Arendt's conception of politics see Sheffield in this volume. 
in the conflict that arises between friendship and humanity with truth. That fact perhaps strikes modern men as even stranger, but once again it is curiously close to the principles and conflicts which concerned classical antiquity. In the end, after all, Nathan's friendship consists solely in his readiness to sacrifice truth to friendship. ${ }^{28}$

Here, in contrast to her earlier interpretations of Nathan, 'humanity' is ranged with 'friendship' as a political relationship which preserves particular distinctions, ranged against the demands of an invariant 'objectivity' or philosophico-religious truth. When Arendt returns to Nathan's parable of the rings it is now to underline her assertation that 'If he [Lessing] had been confronted with the Platonic alternative of doxa and aletheia, of opinion and truth, there is no question how he would have decided':

He was glad that - to use his parable - the genuine ring, if it ever existed, had been lost; he was glad for the sake of the infinite number of opinions that arise when men discuss the affairs of this world. If the genuine ring did exist, that would mean an end to discourse and thus to humanness. ${ }^{29}$

\footnotetext{
${ }^{28}$ Arendt 1968, 25-6, quoting Nathan Act II, Scene 5. Weissberg (2007: 195) is therefore mistaken when she states that 'Arendt does not comment on the fact that Recha and the Templar prove to be siblings'; her next comment, that 'the Templar is able to turn into a true "brother" for Recha', skirts close to being out-of-sympathy with Arendt's account. For Arendt presents the sibling relationship not as a sentimental bond (which would assimilate it to Rousseauian and romantic 'fraternity'), but rather as an example of Aristotelian philia (which, unlike modern 'friendship', can characterise familial bonds).

${ }^{29}$ Arendt 1968, 26.
} 
The contrast with Arendt's earlier interpretation, according to which Nathan's parable rested upon 'the notion that deep inside every human being - despite differences of dogmatic convictions, morals, and conduct - is the same human being', could not be greater. ${ }^{30}$

It is thus as a dramatization of 'the conflict that arises between friendship and humanity with truth', and the valuing of the former over the latter, that Arendt now reads as the lesson of Nathan der Weise, and it is this that for her makes the play a 'classical' drama. ${ }^{31}$ Arendt also sees the classicality as manifest in Lessing's own 'humanity' or philanthrōpia: his overriding concern for both preservation and critical contestation of the plural and frequently conflicting standpoints that make up the world. And it is in virtue of this classicality that Arendt seeks to include him among those 'gathered into a common room': to co-opt him as a contemporary. Overall there is a kind of defiant synchronicity in Arendt's treatment of Lessing, a figure who emerges from her discussion as simultaneously ancient, modern, and contemporary.

\section{Historiography ancient and modern}

Such defiant synchronicity occurs time and time again in Arendt's writings and is characteristic of her historiographic approach. It stands out by contrast to the historiography predominant in the Germany of Arendt's youth, of which she is sharply critical. This is the historicist tradition which celebrated its origins in the writings of Herder and Hegel, reached its apogee in the nineteenth century with the work of Niebuhr and Ranke, and had its authoritative, twentieth-century champion in Friedrich Meinecke. For Arendt (rightly or wrongly) this tradition constitutes modern historical thought; and a subterranean dialogue with Meinecke in particular informs the long exploration of historiography given in the

\footnotetext{
${ }^{30}$ Arendt, 2007b, 3.

${ }^{31}$ Arendt 1968, 25-6.
} 
second essay of Between Past and Future. ${ }^{32}$ The title of this essay, 'The Concept of History: Ancient and Modern', suggests that its approach will be comparative. This is misleading, for instead of comparing ancient and modern historiography Arendt argues instead for their incommensurability.

Arendt's explication of the ancient - or, to be more precise, the 'Greek' - concept of history, has much in common with her well known portrait of Greek political life and can therefore be summarised here briefly. For the Greeks, historical narrative was but one of a number of ways by which they sought to preserve great words and deeds from oblivion. ${ }^{33}$ History was a public and communal form of remembrance, aligned with both (heroic) poetry and the polis as organised, human activities which aimed, in Arendt's words, at a kind of 'earthly immortality'.

Crucially, Arendt does not read this Greek concern for the preservation of words and deeds as a concern to preserve authoritative models or standards of human conduct for future generations. 'Authority', on Arendt's analysis, was unknown to the Greeks, being instead a new and distinctive orientation to the past created by the Roman decision to adopt Greek thought as their own ancestral culture and tradition. ${ }^{34}$ Instead she interprets ancient Greek historiography in terms strikingly similar to her characterisation of Lessing's philanthrōpia: as orientated by the desire to preserve a plurality of standpoints in the understanding that

${ }^{32}$ The footnotes show that she is indeed engaging with Meinecke's Vom geschichtlichem Sinn und vom Sinn der Geschichte (1924), as well as his 1936 magnum opus, Die Entstehung des Historismus.

${ }^{33}$ Arendt 2006a, 41-48, 63.

${ }^{34}$ Arendt 2006a, 104-124. 
these, and nothing else, constitute the humanly shared world. This underlies her comments on ancient- historical 'impartiality':

Impartiality, and with it all true historiography, came into the world when Homer decided to sing the deeds of the Trojans no less than those of the Achaeans, and to praise the glory of Hector no less than the greatness of Achilles. This Homeric impartiality, as it is echoed by Herodotus, who set out to prevent 'the great and wonderful actions of the Greeks and the barbarians from losing their due meed of glory,' is still the highest type of objectivity we know. Not only does it leave behind the common interest in one's own side and one's own people which, up to our own days, characterizes almost all national historiography, but it also discards the alternative of victory or defeat, which moderns have felt expresses the "objective" judgment of history itself, and does not permit it to interfere with what is judged to be worthy of immortalizing praise. It could come to the foreground only after a long experience in polis-life [sic], which to an incredibly large extent consisted of citizens talking with one another. In this incessant talk the Greeks discovered that the world we have in common is usually regarded from an infinite number of different standpoints, to which correspond the most diverse points of view. In a sheer inexhaustible flow of arguments, as the Sophists presented them to the citizenry of Athens, the Greek learned to exchange his own viewpoint, his own "opinion" - the

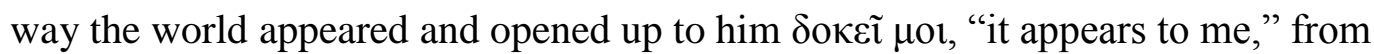
which comes $\delta$ ó $\xi \alpha$, or "opinion" - with those of his fellow citizens. Greeks learned to understand - not to understand one another as individual persons, but to look upon the same world from one another's standpoint, to see the same in very different and frequently opposing aspects. The speeches in which Thucydides makes articulate the 
standpoints and interests of the war ${ }^{35}$ ring parties are still a living testimony to the extraordinary degree of this objectivity. ${ }^{, 36}$

By both present standards of scholarship and those of Arendt's own day, there is much that is contentious in this presentation. Arendt's picture of Thucydides would have seemed particularly scandalous to her contemporaries, for from the eighteenth century onwards he had enjoyed a reputation as a philosophic historian, offering occult wisdom about hidden causes in the working of human affairs, and arguably providing a rather monolithic and authoritative narrative voice. ${ }^{37}$ Arendt's emphasis on the speeches rather than the narrative sections of Thucydides elides this aspect of his work, just as her discussion of Herodotus conveniently skates over his programmatic claim to narrate particularly 'what caused [the

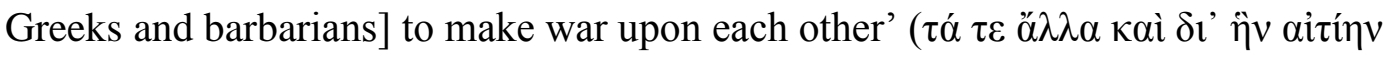
$\dot{\varepsilon} \pi \mathrm{o} \lambda \dot{\varepsilon} \mu \eta \sigma \alpha \nu \alpha \dot{\alpha} \lambda \hat{\eta} \lambda \mathrm{ol \sigma l}$, Hdt. 1.1). Arendt's at-best partial reading of the two most famous Greek historians reflects her hostility to an increasingly deterministic historiographic tradition that had come to emphasise the supra-individual factors in the history of human affairs, allowing room for freedom only in the workings of ineffable and irrational 'genius'.

${ }^{35}$ See for example Meinecke 1972 , lv-lviii.

${ }^{36}$ Arendt 2006a, 51-52. The close implication of the political and the historiographical in this passage's portrait of ancient Greece indicates why Luban (1983) is wrong to present Arendt's understanding of ancient forms of immortalizing as a stadial narrative. Arendt does not argue that the age of Herodotus succeeds that of the polis; rather, and more accurately, she treats the emergence of the polis as a key social and social context shaping both Homeric poetry and classical Greek historiography.

${ }^{37}$ See Harloe and Morley 2012, Morley 2014. 
While less idiosyncratic than her reading of Greek historiography (in its broad outlines it differs little from Meinecke, though not in its valuation of the developments it narrates), Arendt's account of the changes wrought in historical consciousness between antiquity and modernity is equally contentious. ${ }^{38}$ It has many stages: significant changes within antiquity include the advent of Platonic-philosophical thought, which promoted a rival and otherworldly conception of immortality in the shape of contemplative proximity to eternal forms; and of Christianity, which transferred the focus of such hopes from the public world to the individual soul. Further significant changes were set in train with the Scientific Revolution of the sixteenth and seventeenth centuries, which gradually effected a naturalisation of human history alongside its rather swifter historicisation of the natural world. Human political and social formations came to be understood in accordance with metaphors of growth, flowering and fall drawn from the natural world; and attention was refocused from the words and deeds of individuals onto the search for hidden causes and laws, signs of the gradual working out of a logic inherent in history:

The fundamental fact about the modern concept of history is that it arose in the same sixteenth and seventeenth centuries that ushered in the gigantic development of the natural sciences. Foremost among the characteristics of that age, which are still alive and present in our own world, is the world-alienation of man, which I mentioned before and which is so difficult to perceive as a basic condition of our whole life because out of it, and party at least out of its despair, did arise the tremendous structure of the human artifice we inhabit today, in whose framework we have even

\footnotetext{
${ }^{38}$ Arendt 2006a, 48-63.
} 
discovered the means of destroying it together with all non-man-made things on earth. ${ }^{39}$

The genealogy suggested here, which derives Historismus from the scientific conceptions of the age of Bacon and Newton, represents a departure from Meinecke, who characterised it instead as the revolt of living forces against the deadening, mechanistic conceptions of the earlier Enlightenment and the even older Natural Law tradition. Arendt appears to concur more closely with Meinecke in her statement that this form of historical consciousness began to take hold in the generation after Lessing, in the last third of the eighteenth century. ${ }^{40}$ The move nevertheless allows Arendt to connect the history of the historical, as well as the natural, sciences to what she sees one of the fundamental facts of her own time, emphasised throughout Between Past and Future's opening essays: modern man's alienation, turning away from or surrender of the public realm to other imperatives that deform and eventually destroy it.

Here we may again detect a parallel between Arendt's critique of modern historiography and the better-known critical account of 'the rise of the social' she offers in The Human Condition and On Revolution. Just as the French Revolution brought about a revolution in the hierarchy of activities that make up the vita activa, allowing cries of need and biological necessity to erupt and invade political life, so modern historiography has sought to understand human history in categories drawn from the biological life process. ${ }^{41}$ Hegel is, obviously, a significant figure within this account; but Arendt asserts that such thinking is 'characteristic of all modern historical consciousness, however it expresses itself, in

\footnotetext{
${ }^{39}$ Arendt 2006a, 53-5.

${ }^{40}$ Arendt 2006a, 27-8; 68.

${ }^{41}$ The most extensive, though not uncontroversial, study of Arendt's 'social' is Pitkin 1998.
} 
specifically Hegelian terms or not' and that it inspired 'the rise of the humanities in the nineteenth century' ${ }^{42}$ Complementary to this is a new and, in Arendt's eyes, pernicious notion of historical 'objectivity', according to which the historian, refraining from praise or blame, should seek only to 'follow the course of events described in his documentary sources' and to bring to light their inner meaning. ${ }^{43}$ Truth is to-be-revealed in comprehension of the historical process.

For Arendt this is a highly significant shift: it is not going too far to say that she treats the emergence of this mode of historiography in the later eighteenth century as the primary epistemic element of those 'dark times' analysed in her essay on Lessing. ${ }^{44}$ The replacement of the political and philosophical hierarchies bequeathed by Greek and Roman antiquity with various forms of process thinking constitutes the greater part of the break with tradition and authority which, so she argues throughout Between Past and Future, governed Western thought - whether political, historiographic or scientific, Enlightenment or Romantic - into the modern age. In 'What is Authority?' Arendt declares that that this shift in historical consciousness underlies the more superficial ideological distinctions attended to by historians of political thought:

It is... in the nature of the very image in which history is usually conceived, as process or stream or development, that everything comprehended by it can change into anything else, that distinctions become meaningless because they are submerged, as it were, by the historical stream, the moment they have appeared. From this viewpoint, liberalism and conservatism present themselves as the political philosophies which

\footnotetext{
42 Arendt 2006, 68-9.

${ }^{43}$ Arendt 2006, 49 (with explicit reference to Ranke).

${ }^{44}$ Arendt 1968, 30.
} 
correspond to the much more general and comprehensive philosophy of history of the nineteenth century. In form and content, they are the political expression of the history-consciousness of the last stage of the modern age. Their inability to distinguish, theoretically justified by the concepts of history and process, progress or doom, testifies to an age in which certain notions, clear in their distinctness to all previous centuries, have begun to lose their clarity and plausibility because they have lost their meaning in the public-political reality - without altogether losing their significance. $^{45}$

Finally, in ways that have been explored in Arendt scholarship, the deterministic trust in historical process, surrender of judgement and lack of distinction involved in this philosophy of history both paved the way for and were implicated in the worst horrors of totalitarian domination. ${ }^{46}$ For, as she insists in an essay contemporaneous with The Origins of Totalitarianism, neither the means employed by the Nazi regime ('wars of aggression', 'massacres and exterminations', slavery and forced labour), nor their most obvious result (death on a massive scale), were unprecedented. ${ }^{47}$ In Origins itself, she argues that what distinguishes totalitarian government from all prior forms is its brazen disregard of that distinction between lawfulness and lawlessness which was a hallmark of all prior forms of government in favour of direct submission to the supposed 'laws' of 'Nature' or 'History', as given in the supposedly eternal struggle of races or classes:

It is the monstrous, yet seemingly unanswerable claim of totalitarian rule that, far from being "lawless," it goes to the sources of authority from which positive laws

\footnotetext{
${ }^{45}$ Arendt 2006a, 101.

${ }^{46}$ See for example Benhabib 1990, 171-80; Disch 1993; Aharony 2010.

${ }^{47}$ Arendt 1950, 50-51.
} 
received their ultimate legitimation, that far from being arbitrary it is more obedient to these suprahuman forces than any government ever was before, and that far from wielding its power in the interest of one man, it is quite prepared to sacrifice everyone's vital immediate interests to the execution of what it assumes to be the law of History or the law of Nature. ${ }^{48}$

The result is the regime Arendt famously likens to an 'iron band' that '[b]y pressing men against each other... destroys the space between them'. Totalitarianism goes beyond the curtailing of individual freedom to accomplish the destruction of personhood and individuality itself, and it does so in the name of the historical process. ${ }^{49}$

To return to Arendt's Lessing essay, the terms she used in Origins to describe what totalitarianism annihilates ('It destroys the one essential prerequisite for all freedom which is simply the capacity of motion which cannot exist without space ${ }^{50}$ ) are echoed in her gloss on what she calls 'Lessing's famous Selbstdenken - independent thinking for oneself':

For Lessing, thought does not arise out of the individual and is not the manifestation of a self. Rather, the individual - whom Lessing would say was created for action, not ratiocination - elects such thought because he discovers in thinking another mode of moving in the world in freedom. ${ }^{51}$

\footnotetext{
${ }^{48}$ Arendt 1976, 461-2, see more generally this entire chapter ('Ideology and Terror: A Novel Form of Government').

${ }^{49}$ Arendt 1976, 466.

${ }^{50}$ Arendt 1976, 466.

${ }^{51}$ Arendt 1968, 9.
} 
Although this is not the case in Origins (where Arendt still holds to a view of Lessing as exemplifying the limitations of Enlightenment 'toleration'), in her later writings she invokes Lessing's Selbstdenken more than once as a counterweight to modern currents of thought and practice that threaten the public realm. For example, 'Truth and Politics' (an essay composed for The New Yorker in 1967 and subsequently included in the second edition of Between Past and Future) includes an appeal to 'Lessing's magnificent "Sage jeder, was ihm Wahrheit dünkt, und die Wahrheit selbst sei Gott empfohlen" ("Let each man say what he deems truth, and let truth itself be commended unto God")' as the antithesis of the antipolitical truth-seeking of Platonic and Parmenidean philosophy. ${ }^{52}$ And in The Human Condition itself, Arendt turns to Lessing to articulate a response to the emptiness and ultimate nihilism of the kind of means-end reasoning recognised as sovereign in the world of homo faber:

Obviously there is no answer to the question which Lessing once put to the utilitarian philosophers of his time: “And what is the use of use?" The perplexity of utilitarianism is that it gets caught in the unending chain of means and ends without ever arriving at some principle which could justify of the category of means and end, that is, of utility itself. The "in order to" has become the content of the "for the sake of'; in other words, utility established as meaning generates meaninglessness. ${ }^{53}$

Here again, Lessing stands for an attitude that resists the anti-political and ultimately fateful turns of thought detailed in Arendt's history of ideas. It is therefore perhaps unsurprising that Arendt's final 'proof' of Lessing's commitment to friendship and humanity over truth in 'On

\footnotetext{
${ }^{52}$ Arendt 2006a, 229; compare Arendt 1968, 27.

${ }^{53}$ Arendt 1968, 154.
} 
Humanity in Dark Times' also makes reference to the death camps. ${ }^{54}$ Challenging her (postwar, German) audience to 'assume for the moment that the [Nazi] racial theories could have been convincingly proved', and to set aside the traditional Christian prohibition on murder, she asks them to consider how they would answer the question 'Would any such doctrine, however convincingly proved, be worth the sacrifice of so much as a single friendship between two men?' To declare that 'Lessing would not have found any difficulty in answering the question I have just posed' is Arendt's way of demonstrating both the courageousness of Lessing's cherishing of the public realm and what is at stake in the preservation or loss of this attitude in modernity, underlining why 'We very much need Lessing to teach us this state of mind'. ${ }^{55}$

3. Between past and future: Remembrance and resistance

The political relevance of Lessing's philanthroppia or 'humanity' is therefore clear. What of his relevance to Arendtian practice of historiography? Arendt's analysis suggests that the grasp of process thinking on modern thought about history and society is all but absolute. The break in tradition inaugurated at the dawn of the 'modern age' and completed by the practices of totalitarian domination is fundamental and irreversible. She maintains nevertheless that some kind of orientation to the past still has a vital role to play in human living together:

[I] t cannot be denied that without a securely anchored tradition - and the loss of this security occurred several hundred years ago - the whole dimension of the past has

\footnotetext{
${ }^{54}$ Petuchowski 1988 includes an interesting discussion of the structural affinity of Arendt's essay to a classical rhetorical speech composed of exordium, narratio, confirmatio and peroration.

55 Arendt 1968, 29, 8.
} 
been endangered. We are in danger of forgetting, and such an oblivion - quite apart from the contents themselves that could be lost - would mean that, humanly speaking, we would deprive ourselves of one dimension, the dimension of depth in human existence. For memory and depth are the same, or rather, depth cannot be reached by man except through remembrance. ${ }^{56}$

The terms Arendt chooses here to expresses her concern for the past, as a dimension of human existence that is 'endangered' and (by implication) stands in need of championing, are reminiscent of her characterisation of Lessing's concern for the kind of worldly diversity that cherishes plurality over 'objective' truth. And it is surely significant that Arendt characterises this form of orientation to the past as 'remembrance', the term she reserved for the Greek, rather than the modern, concept of history. What might constitute such remembrance within her analysis of the contemporary world, and why might it matter?

An answer is perhaps provided by the description Arendt gives in Eichmann in Jerusalem of the reaction of the courtroom to the testimony of Abba Kovner, the Israeli poet and former Polish resistance fighter, about help given the partisans by a German army officer, Anton Schmidt:

During the few minutes it took Kovner to tell of the help that had come from a German sergeant, a hush settled over the courtroom; it was as though the crowd had spontaneously decided to observe the usual two minutes of silence in honor of the man named Anton Schmidt. And in those two minutes, which were like a sudden burst of light in the midst of impenetrable, unfathomable darkness, a single thought stood out clearly, irrefutably, beyond question - how utterly different everything

\footnotetext{
${ }^{56}$ Arendt 2006a, 94.
} 
would be today in this courtroom, in Israel, in Germany, in all of Europe, and perhaps in all countries of the world, if only more such stories could have been told. ${ }^{57}$

This notion of historiography, focused on deeds and words that stand out against their background as acts of freedom and resistance, might also encompass Kovner's own story, as well as those chapters of Eichmann that detail the variations in response of occupied nations to the command to round up their Jewish populations for internment. It also fits Men in Dark Times, with its focus on figures whose lives and actions Arendt indeed presents as 'determined', but not fully 'conditioned', by the political and social contexts in which they lived. ${ }^{58}$ What is preserved in such stories is, as a minimum, the bare possibility of doing otherwise than the 'spirit of the age' seems to demand. This may seem rather thin as an account of the possible relation of past and present, but Arendt clearly finds it significant:

For the lesson of such stories is simple and within everyone's grasp. Politically speaking, it is that under conditions of terror most people will comply but some people will not... Humanly speaking, no more is required, and no more can reasonably be asked, for this planet to remain a place fit for human habitation. ${ }^{59}$

It is in this context that we should address a final significant citation of Lessing in Arendt's work: in the course of the public exchange of letters with Gershom Scholem in the aftermath of Eichmann's publication. ${ }^{60}$ In summer 1963, at the height of the furore that attended the book's appearance, Scholem wrote to Arendt 'somewhat more temperately than most', as

\footnotetext{
${ }^{57}$ Arendt 2006b, 231,233.

${ }^{58}$ Arendt 1968, vii.

${ }^{59}$ Arendt 2006b, 233.

${ }^{60}$ Arendt and Scholem, 1964. Arendt's side of the exchange is reprinted in Arendt 2007a,
} $465-71$. 
Jerome Kohn has remarked, but nevertheless taking her to task for her stance concerning 'the Jews and their bearing in the days of catastrophe'. ${ }^{61}$ Scholem criticises Arendt for speaking 'At each decisive juncture... only of the weakness of the Jewish stance in the world', for convicting Jewish leaders of complicity in the round-ups and forced migrations, and overall for presuming to judge about matters 'complex and serious... little reducible or transparent', about which his and Arendt's generation, 'lack[ing] the necessary perspective, which alone makes some sort of objectivity possible', is 'not in a position to pass any kind of historical judgement'. He also reproaches Arendt as a Jew, accusing her of having shown insufficient sympathy towards her own people:

In the Jewish tradition there is a concept, hard to define and yet concrete enough, which we know as Ahabath Israel: "Love of the Jewish people..." In you, dear Hannah, as in so many intellectuals who came from the German Left, I find little trace of this. A discussion such as is attempted in your book would seem to me to require... the most old-fashioned, the most circumspect, the most exacting treatment possible precisely because of the feelings aroused by this matter, this matter of the destruction of one-third of our people - and I regard you wholly as a daughter of her people, and in no other way... In circumstances such as these, would there not have been a place for what I can only describe with that modest German word - "Herzenstakt"? ${ }^{62}$

It is a remarkable feature of Arendt's reply that she devotes as much time to contesting Scholem's address to her in these terms as to defending her account of the trial evidence and the issues it raised. She states that she 'found it puzzling that you should write "I regard you wholly as a daughter of our own people, and in no other way",' since

\footnotetext{
${ }^{61}$ Kohn in Arendt 2007a, b465; Arendt and Scholem 1964, 51.

${ }^{62}$ Arendt and Scholem 1964, 51-2.
} 
The truth is that I have never pretended to be anything else or to be in any way other than I am, and I have never even felt tempted in that direction. It would have been like saying that I was a man and not a woman - that is to say, kind of insane... I have always regarded my Jewishness as one of the indisputable factual data of my life, and I have never had the wish to change or disclaim facts of this kind. There is such a thing as a basic gratitude for everything that is as it is; for what has been given and was not, couldnot be, made; for things that are physei and not nomō. To be sure, such an attitude is pre-political, but in exceptional circumstances - such as the circumstances of Jewish politics - it is bound also to have political consequences though, as it were, in a negative way. ${ }^{63}$

She nevertheless concedes something to Scholem's larger point:

You are quite right - I am not moved by any "love" of this sort, and for two reasons: I have never in my life "loved" any people or collective - neither the German people, nor the French, nor the American, nor the working class or anything of that sort. I indeed love 'only' my friends and the only kind of love I know of and believe in is the love of persons. Secondly, this 'love of the Jews' would appear to me, since I am myself Jewish, as something rather suspect. I cannot love myself or anything which I know is part and parcel of my own person. ${ }^{64}$

Arendt characterises her attitude towards her own Jewishness as 'pre-political', but as her words above make clear, this does not mean she sees her Jewish identity as a 'fact' with no political relevance. Her treatment of the same theme in the Lessing essay underlines this, with her declaration (again the German, post-war audience should be borne in mind) that 'I cannot

\footnotetext{
${ }^{63}$ Arendt and Scholem 1964, 53-4.

${ }^{64}$ Arendt and Scholem 1964, 54.
} 
gloss over the fact that for many years I considered the only adequate reply to the question, Who are you? to be: A Jew. That answer alone took into account the reality of persecution. ${ }^{65}$ What Arendt denies is that this 'fact' should in any way have governed the standpoint she took up in her narration of the Eichmann trial, or that a call to sympathy or compassion with her 'own people' should have conditioned her writing:

Generally speaking, the role of "heart" in politics seems to me altogether questionable. You know as well as I do how often those who merely report certain unpleasant facts are accused of lack of soul, lack of heart, or lack of what you call Herzenstakt. We both know, in other words, how often these emotions are used in order to conceal factual truth. I cannot discuss here what happens when emotions are displayed in public and become a factor in political affairs; but it is an important subject, and I have attempted to describe the disastrous results in my book $\mathrm{On}$ Revolution in discussing the role of compassion in the formation of the revolutionary character. $^{66}$

In her reply Arendt rejects both Scholem's claim that she ought to have have refrained from judgement and his complaint that she should have written from a standpoint informed by fraternity with the Jewish people. It is in the context of her resistance to his attempt to hail her as a 'daughter of Israel' that Arendt again invokes Lessing as a defender of impartiality and freedom of thought and speech:

${ }^{65}$ Arendt 1968, 17; compare her claim to Scholem that 'in exceptional circumstances - such as the circumstances of Jewish politics - it is bound to have also political consequences though, as it were, in a negative way' (Arendt and Scholem 1964, 54); and see the excellent discussion in Disch 1995, 292-4.

${ }^{66}$ Arendt and Scholem, 1964,54. 
What confuses you is that my arguments and my approach are different from what you are used to; in other words, the trouble is that I am too independent. By this I mean, on the one hand, that I do not belong to any organisation and always speak out only for myself, and on the other hand, that I have great confidence in Lessing's selbstdenken [sic] for which, I think, no ideology, no public opinion, and no "convictions" can ever be a substitute. Whatever objections you have to the results, you won't understand them unless you realise that they are really my own and nobody else's. $^{67}$

\section{Conclusion}

In 'What is Authority?' Arendt writes:

'[T]he undeniable loss of tradition in the modern world does not at all entail a loss of the past, for tradition and past are not the same, as the believers in tradition on one side and the believers in progress on the other would have us believe - whereby it makes little difference that the former deplore this state of affairs while the latter extend their congratulations. With the loss of tradition we have lost the thread which safely guided us through the vast realms of the past, but this thread was also the chain fettering each successive generation to a predetermined aspect of the past. It could be that only now will the past open up to us with unexpected freshness and tell us things no one has yet had ears to hear. ${ }^{68}$

In this passage, as so often, Arendt emphasises the rupture with past thought and experience that was completed in the twentieth century but was underway even at the outset of the

\footnotetext{
${ }^{67}$ Arendt and Scholem 1964, 55.

${ }^{68}$ Arendt 2006, 93-4.
} 
'modern age'. ${ }^{69}$ Arendt's invocation of Greek antiquity should not be understood as idealisation of a past social and political formation as a model for the present in any substantive sense, for to do so would be to subscribe to a model of authority, of the continuing relevance of a particular foundational moment in the past, which according to her has lost all purchase. Nor, however, is her account of the genesis of modernity as a form of quasi-Heideggerian Verfallsgeschichte; for, as she points out in 'The Concept of History', both the historiography of 'progress' and that of 'decline' cleave to a framework of 'tradition' and 'authority' which is now lost.

Given the extinction of alternatives, the only possibility for those now left wandering in the gap between past and future and wondering how to reestablish a connection to the past can be a relation which does not rely on notions of authority or tradition. Historically speaking, the only point of reference for this orientation can be the Greeks, to whom the notions of authority and tradition were unknown. ${ }^{70}$ Arendt finds in both the polis and in Greek historiography that concern for maintenance of a plural human world that she also detects in Lessing. This causes her to characterise him as both 'political', in terms of his manifest concern for the world, and as 'classical'. Her approach may be ahistorical by the lights of the Historismus dominant in her youth, which she criticises in 'The Concept of History: Ancient and Modern'. But it is historical - as well as eminently political - in the Arendtian sense. Her allegiance to this conception aligns her own writings with the political historiography she attributes to Herodotus and Thucydides and makes of her, as she makes of Lessing, both an ancient and a contemporary.

\section{Harloe Arendt and the Quarrel of Ancient and Modern Bibliography.}

\footnotetext{
${ }^{69}$ Arendt 2006, 26, 91.

${ }^{70}$ See section 2 above.
} 
Author-final copy

Agamben, Giorgio. 2005. State of Exception. Chicago and London.

Aharony, Michal. 2013. Hannah Arendt and the Idea of Total Domination. Holocaust and Genocide Studies 24.2: 193-224.

Arendt, Hannah. 1950. Social Science Techniques and the Study of Concentration Camps. Jewish Social Studies 12.1: 49-64.

Arendt, Hannah. 1960. Von der Menschlichkeit in finsteren Zeiten. Rede über Lessing. Munich.

Arendt, Hannah., and Gershom Scholem. 1964. "Eichmann in Jerusalem": An Exchange of Letters between Gershom Scholem and Hannah Arendt. Encounter 22: 51-6.

Arendt, Hannah. 1970. On Violence. New York, San Diego and London.

Arendt, Hannah. 1976. The Origins of Totalitarianism. New edn. with added prefaces. San Diego, New York and London.

Arendt, Hannah. 1968. Men in Dark Times. New York.

Arendt, Hannah. 1978. The Jew as Pariah: Jewish Identity and Politics in the Modern Age, ed. Ron H. Feldman. New York.

Arendt, Hannah, and Karl Jaspers. 1985. Hannah Arendt/Karl Jaspers Briefwechsel, ed. Lotte Köhler and Hans Sahler. Munich.

Arendt, Hannah, and Kurt Blumenfeld. 1995. In keinem Besitz verwurzelt : die Korrespondenz, ed. Ingeborg Nordmann and Iris Pilling. Hamburg.

Arendt, Hannah. 1996. Love and Saint Augustine, ed. Joanna Vecchiarelli Scott and Judith Chelius Stark. Chicago and London. 
Author-final copy

Arendt, Hannah. Rahel Varnhagen: The Life of a Jewess, ed. Liliane Weissberg, tr. Richard and Clara Winston. Baltimore.

Arendt, Hannah. 1998. The Human Condition. $2^{\text {nd }}$ edn. Chicago.

Arendt, Hannah. 2002. Denktagebuch: 1950 bis 1973, ed. Ursula Ludz and Ingeborg Nordmann. Munich.

Arendt, Hannah. 2006a. Between Past and Future: Eight Exercises in Political Thought. London.

Arendt, Hannah. 2006b. Eichmann in Jerusalem: A Report on the Banality of Evil. London. Arendt, Hannah. 2007a. The Jewish Writings, ed. Jerome Kohn and Ron H. Feldman. New York.

Arendt, Hannah. 2007b. The Enlightenment and the Jewish Question, in Arendt 2007a, 3-18.

Butler, E. M. 1935. The Tyranny of Greece over Germany: A Study of the Influence Exercised by Greek Art and Poetry Over the Great German Writers of the Eighteenth, Nineteenth and Twentieth Centuries. Cambridge.

Butler, Judith. 2011. Hannah Arendt's Death Sentences. Comparative Literature Studies 48.3: 280-95.

Butler, Judith. 2015. Notes Toward a Performative Theory of Assembly. Cambridge, MA.

Benhabib, Seyla. 1990. Hannah Arendt and the Redemptive Power of Narrative. Social Research 57.1: 167-96.

Benhabib, Seyla. 1993. Feminist Theory and Hannah Arendt's Concept of Public Space. History of the Human Sciences 6: 97-114. 
Author-final copy

Benhabib Seyla. 1996. The Reluctant Modernism of Hannah Arendt. Thousand Oaks, CA.

Benhabib, Seyla. 2002. The Claims of Culture: Equality and Diversity in the Global Era.

Princeton.

Benhabib, Seyla. 2006. Democracy and Difference: Contesting the Boundaries of the

Political. Princeton.

Davies, Steffan. 2015. Exile and Enlightenment: The appropriation of Lessing, 1929-1959.

Forum for Modern Language Studies 51.2: 186-211.

De Geus, M.A. 2007. Towards an ecological art of living: On the value of ecological utopias for our future. Ecopolitics Online Journal 1.1: 26-51.

Disch, Lisa J. 1993. More Truth than Fact: Storytelling as Critical Understanding in the Writings of Hannah Arendt. Political Theory 21.4: 665-94.

Disch, Lisa M. 1995. On Friendship in Dark Times, in Honig 1995a, 285-312.

Eigen, Sara. 2000. Hannah Arendt's 'Lessing Rede' and the 'Truths' of History. Lessing Yearbook 32: 309-24,

Harloe, Katherine and Morley, Neville. 2012. Thucydides and the Modern World. Reception, Reinterpretation and Influence from the Renaissance to Today. Cambridge.

Honig, Bonnie. 1993. Political Theory and the Displacement of Politics. Ithaca, NY.

Honig, Bonnie. 1995a. Feminist Interpretations of Hannah Arendt. University Park, PA.

Honig, Bonnie. 1995b. ‘Towards an Agonistic Feminism'. In Honig 1995a, 135-66.

Honig, Bonnie. 2015. Public Things: Jonathan Lear's Radical Hope, Lars von Trier's Melancholia, and the Democratic Need. Political Research Quarterly 28.3: 623-36. 
Author-final copy

Leonard, Miriam. 2012. Socrates and the Jews: Hellenism and Hebraism from Moses Mendelssohn to Freud. Chicago and London.

Lessing, Gotthold Ephraim. 1890. Gotthold Ephraim Lessings sämtliche Schriften, ed. Karl Lachmann; 3rd edn. revised by Franz Muncker. Volume 5. Stuttgart.

Luban, David. 1983. Explaining Dark Times: Hannah Arendt's Theory of Theory. Social Research 50.1: 215-48.

Meinecke, Friedrich. 1936. Die Entstehung des Historismus. Munich and Berlin.

Meinecke, Friedrich. 1939. Vom geschichtlichem Sinn und vom Sinn der Geschichte.

Leipzig.

Meinecke, Friedrich. 1972. Historism. The Rise of a New Historical Outlook, tr. J.E, Anderson, foreword by Isaiah Berlin. London.

Morley, Neville. 2014. Thucydides and the Idea of History. London.

Petuchowski, Elizabeth A. 1988. Hannah Arendt's Von der Menschlichkeit in finsteren Zeiten: A Post-World War II Address. Lessing Yearbook 20: 29-43.

Pitkin, Hanna Fenichel. 1981. Justice: On Relating Private and Public. Political Theory 9.3: $327-52$.

Pitkin, Hanna Fenichel. 1998. The Attack of the Blob: Hannah Arendt's Concept of the Social. Chicago.

Weissberg, Liliane. 2007. Humanity and its Limits: Hannah Arendt Reads Lessing. In Practicing Progress: The Promise and Limitations of Enlightenment. Festschrift for John A. McCarthy, ed. Richard E. Schade and Dieter Sevin, 187-198. Amsterdam and New York. 
Author-final copy

Voice, Paul. 2013. On Consuming the World: Hannah Arendt on Politics and the Environment. Journal of International Political Theory 9.2: 178-93.

Young-Bruehl, Elisabeth. 1982. Hannah Arendt: For Love of the World. New Haven and London. 